Apidologie, 1986, 17 (2), 93-100

\title{
INFECTIVITY AND SURVIVAL OF THE CHALKBROOD PATHOGEN, ASCOSPHAERA APIS, IN COLONIES OF HONEY BEES, APIS MELLIFERA
}

\author{
Martha GILLIAM \\ U.S. Department of Agriculture, Carl Hayden Bee Research \\ Center, 2000 E. Allen Road, Tucson, Arizona 85719
}

\begin{abstract}
SUMMARY
To gain insight into the recurring nature of chalkbrood disease in honey bee colonies, suspensions of Ascosphaera apis prepared from sporulated chalkbrood mummies were sprayed triweekly on the brood combs and the bees around the brood of colonies for four months beginning in August. For nine months, mummies were collected from dead bee traps and bottom boards and were counted in comb cells. For seven months, bees, brood, and hive products were tested for $A$. apis by microbiological plating procedures.

Two major periods of infection occurred. The first was one week after spray inoculation began, and the second took place in November and seemed related to nutritional stress. Susceptibility of the inoculated colonies to the disease varied from nil to high. Five months were required after the last spray before most substrates in the colonies were free of $A$. apis, although low level contamination still persisted in bee bread, honey, and the interior of larvae from capped cells. The pathogen can survive in bee colonies without causing overt disease.
\end{abstract}

This paper reports the results of an experiment designed to gain insight into the recurring or cyclic nature of the fungal disease, chalkbrood, in colonies of honey bees, Apis mellifera. The influence of a constant source of inoculum on the incidence of chalkbrood and the survival of the pathogen, Ascosphaera apis, in bee colonies were examined. Randomly selected colonies rather than genetically identical ones were used to reflect the usual situation.

On August 19, frames of brood and stores and populations of adult bees were equalized as much as possible in 13 two-story colonies with no recent history of chalkbrood disease. Dead bee traps were placed on all colonies. Then comb cells, traps, and bottom boards were checked daily for one week for chalkbrood mummies prior to the initial inoculation with $A$. apis. No mummies were found. 
Suspensions for each spray inoculation were freshly prepared by homogenizing three black mummies in $5 \mathrm{ml}$ of $5 \%(\mathrm{w} / \mathrm{v})$ sucrose syrup. Then $85 \mathrm{ml}$ of sucrose syrup was added to the homogenate. Suspensions were always plated on Sabouraud dextrose agar with $0.2 \%$ yeast extract to test for viability and purity (Gilliam et al., 1983). For four months (Aug. 25-Dec. 19), each of 12 colonies was inoculated three times a day each Monday, Wednesday, and Friday by spraying with a hand-held garden sprayer $90 \mathrm{ml}$ of suspension on all the brood frames and the bees around the brood. Initially, all colonies contained seven or eight frames of brood. Using the spore counts per mummy obtained by GochNAUER and MARGETTS (1980), each colony received a total of approximately $6 \times 10^{10}$ spores. The uninoculated control colony at another location in the area was used to monitor natural infection. Controls sprayed with sucrose syrup were not utilized because the stress from the additional manipulations could have caused an increase in chalkbrood and hence an unrealistic estimate of natural infection. Also, because of the labor-intensive nature of this work, I elected to inoculate with the pathogen and then monitor as many colonies as possible.

For nine months (Aug. 19-May 4), chalkbrood mummies were counted in comb cells once a week and were collected from bottom boards and dead bee traps three times a week. Approximately once a month for seven months (Oct. 14May 22), five samples each of larvae from uncapped cells, larvae from capped cells, nurse bees, foragers, honey, and bee bread were tested for viable $A$. apis by microbiological plating procedures described previously (GILliam et al., 1983). The body surfaces of larvae and worker bees as well as the interiors of larvae and the guts of worker bees were examined for the pathogen.

The first chalkbrood mummies were found one week after the spray inoculations began (Table 1). This major peak of infection seemed related to inoculum load and to stress resulting from frequent manipulations required at the onset of the test. Another major peak of infection occurred around November 1 and appeared related to nutritional stress since most colonies had little stored honey, and pollen collection was dwindling. Colonies were given two feedings of sugar syrup in early November, and by the middle of the month, pollen was again being collected. A minor peak of infection occurred in some colonies around December 1 and may have been related to the stress of too few young worker bees to care for the increasing brood.

The variation in susceptibility of bee colonies to chalkbrood disease is emphasized by the fact that one inoculated colony (8), like the control colony, never had chalkbrood, and two colonies ( 7 and 9) had very light infections. Some colonies (1, 4, and 12) had heavy infections, but even among these, there were differences. Most mummies from colony 1 were found on only two dates. However, colony 12 appeared to have a more persistent infection and/or mummy removal required more time. Thus, colony 8 was the most resistant to chalkbrood, and colony 12 was quite susceptible. 
TABL. 1. - Number of chalkbrood mummies collected from dead bee traps and bottom boards

\begin{tabular}{|c|c|c|c|c|c|c|c|c|c|c|c|c|c|c|}
\hline \multirow{2}{*}{ Week of } & \multicolumn{12}{|c|}{ Inoculated colonies } & \multirow{2}{*}{$\begin{array}{l}\text { Control } \\
\text { colony }\end{array}$} & \multirow{2}{*}{ Total } \\
\hline & 1 & 2 & 3 & 4 & 5 & 6 & 7 & 8 & 9 & 10 & 11 & 12 & & \\
\hline $9 / 1$ & 296 & 93 & 302 & 950 & 81 & 41 & 0 & 0 & 0 & 41 & 211 & 62 & 0 & 2077 \\
\hline $9 / 8$ & 0 & 9 & 37 & 74 & 0 & 2 & 0 & 0 & 0 & 0 & 4 & 17 & 0 & 143 \\
\hline $9 / 15$ & 0 & 0 & 64 & 3 & 0 & 2 & 0 & 0 & 0 & 0 & 11 & 0 & 0 & 80 \\
\hline $9 / 22$ & 0 & 0 & 0 & 0 & 0 & 0 & 0 & 0 & 0 & 0 & 0 & 85 & 0 & 85 \\
\hline $9 / 29$ & 0 & 0 & 0 & $\mathbf{0}$ & 0 & 0 & 0 & 0 & 0 & 0 & 0 & 7 & 0 & 7 \\
\hline $10 / 6$ & 0 & 0 & 12 & 0 & 0 & 0 & 0 & 0 & 0 & 0 & 0 & 0 & 0 & 12 \\
\hline $10 / 13$ & 0 & 0 & 0 & 0 & 0 & 0 & 0 & 0 & 0 & 0 & 0 & 0 & 0 & 0 \\
\hline $10 / 20$ & 0 & 0 & 1 & 4 & 7 & 0 & 0 & 0 & 0 & 0 & 0 & 478 & 0 & 490 \\
\hline $10 / 27$ & 31 & 0 & 27 & 11 & 13 & 19 & 0 & 0 & 0 & 0 & 79 & 99 & 0 & 279 \\
\hline $11 / 3$ & 407 & 4 & 53 & 264 & 97 & 29 & 1 & 0 & 0 & 11 & 29 & 18 & 0 & 913 \\
\hline $11 / 10$ & 0 & 0 & 5 & 5 & 0 & 0 & 8 & 0 & 0 & 70 & 0 & 10 & 0 & 98 \\
\hline $11 / 17$ & 0 & 0 & 0 & 0 & 1 & 0 & 0 & 0 & 1 & 1 & 0 & 13 & 0 & 16 \\
\hline $11 / 24$ & 0 & 0 & 2 & 0 & 0 & 0 & 0 & 0 & 1 & 2 & 0 & 46 & 0 & 51 \\
\hline $12 / 1$ & 0 & 0 & 0 & 0 & 0 & 7 & 1 & 0 & 10 & 93 & 3 & 14 & 0 & 128 \\
\hline $12 / 8$ & 4 & 0 & 0 & 0 & 0 & 0 & 0 & 0 & 0 & 11 & 0 & 11 & 0 & 26 \\
\hline $12 / 15$ & 0 & 0 & 0 & 0 & 0 & 0 & 0 & 0 & 0 & 0 & 0 & 0 & 0 & 0 \\
\hline $12 / 22-5 / 4$ & 0 & 0 & 0 & 0 & 0 & 0 & 0 & 0 & 0 & 0 & 0 & 0 & 0 & 0 \\
\hline Total & 738 & 106 & 503 & 1311 & 199 & 100 & 10 & 0 & 12 & 229 & 337 & 860 & 0 & 4405 \\
\hline
\end{tabular}

No mummies were found in any colonies after December 8 even though the spray inoculations continued through December 19. Either proper conditions for infection did not exist, stresses were not present, and/or some resistance to the pathogen developed. Of the 4405 mummies collected, 2871 were black due to sporulation of the fungus; 1534 were white and contained only mycelia. We have noted the production of white mummies from sporulated inocula in our previous work (GILliam et al., 1983) and recently found that $40.5 \%$ of mummies lacking ascocarps that we examined contained both + and - mating types (Christensen and Gilliam, 1983). Three pupae mummified by $A$. apis were collected in the present test and confirm our earlier assertion that mummified pupae are occasionally found (Gilliam et al., 1983).

Often less than 10 mummies would be seen in the comb cells of a colony, but they would not be seen in the traps or on bottom boards until a weak or more later. This indicates poor hygienic behavior of the adult bees. In this test as well as our previous work (GiLliam et al., 1983), fewer mummies were seen in comb cells than were eventually found in the traps indicating that the bees can detect diseased larvae before we can and remove them and/or that we underestimated the numbers of mummies in capped cells. 
Throughout the nine months of this test, temperature and rainfall seemed to have little effect of the incidence of chalkbrood. However, Tucson is located in the Sonoran Desert and has a mild climate with only about $254 \mathrm{~mm}$ of rainfall annually. For example, the average maximum temperature in November during the test was $26.3^{\circ} \mathrm{C}$, the average minimum was $4.3^{\circ} \mathrm{C}$, and there was no rainfall. This experiment was discontinued in May, but these colonies have been maintained for other purposes and have not had chalkbrood.

Table 2 shows the results of cultural detection of $A$. apis in the bee colonies. In the control colony, bee bread and the guts of nurse bees yielded the highest number of positive samples. This agrees with our earlier data obtained from colonies that had been sprayed with $A$. apis spores for two months (Gilcram et al., 1983). Even though $A$. apis was found in the control colony in January and February, no mummies were ever seen. In January, $60 \%$ of the guts of foraging bees from the control colony contained $A$. apis; in February, this decreased to $20 \%$ and was the only positive sample in the colony. During a recent experiment concerned with microflora of bee guts, we frequently isolated $A$. apis from worker bees from a colony that has never had chalkbrood. Thus, the pathogen can survive in bee colonies without causing chalkbrood disease.

In October, there was no bee bread in the inoculated colonies to sample. However, $68 \%$ of the samples of bee bread obtained in November contained viable $A$. apis. The highest percent of samples positive for $A$. apis in inoculated colonies occurred in honey. Guts of nurse bees also had a high percent of positive samples which could have resulted from consumption of contaminated pollen.

Five months were required, after the last spray inoculation, for most substrates to be free of $A$. apis, although a low level of contamination still persisted in bee bread, honey, and the interior of larvae from capped cells. The highest percent of positive results within each type of sample occurred in November after the spray inoculations had been in progress for two and one-half months or in December-January, one to two weeks after the inoculations had ceased.

The most resistant colony, colony 8 , with the exception of the November samples, had $55 \%$ fewer total samples contaminated with $A$. apis than did colony 12 , the most susceptible one. The pathogen survived longer and on more substrates in colony 12 .

In conclusion, these results support BAILEY (1967) who characterized A. apis as an opportunistic pathogen that kills individual larvae only when they are subjected to other stresses. Even though $A$. apis was sprayed for four months, only two periods of major infection occurred. Thus, since the pathogen is often present in bee colonies which never show symptoms of the disease, breeding of 


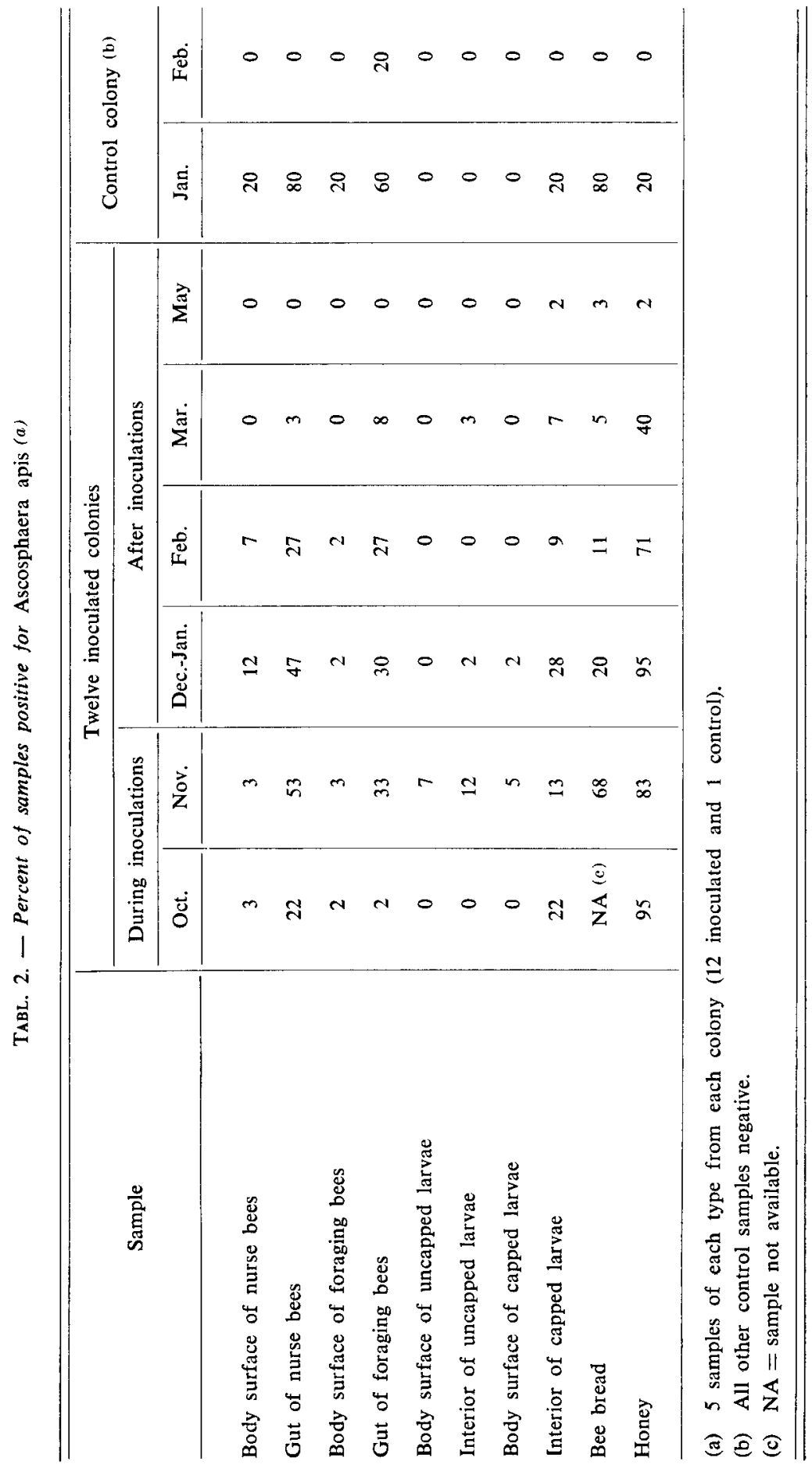


queen bees from such colonies would seem a logical approach for control. A better approach would be to breed queens from colonies that have been exposed to but have never carried $A$. apis if such colonies could be found. We need to know why only some bee colonies and larvae are susceptible and what the triggering mechanisms are for production of the disease. Also, stress factors in various geographical areas should be examined in relation to the expression of the disease. For example, in Tucson, heat and lack of rainfall may be more important than the stresses of high humidity and cold temperatures which are frequently cited. This is clearly a disease in which the dynamics of the pathogen and of the bee colony need to be explored in unison.

\title{
ACKNOWLEDGMENT
}

I thank Brenda Lorenz for skilled technical assistance.

Received for publication in July 1985. Accepted for publication in December 1985

\author{
RESUMÉ \\ POUVOIR INFECTIEUX ET SURVIE DE L'AGENT DU COUVAIN PLATRE, \\ ASCOSPHAERA APIS, DANS LES COLONIES D'ABEILLE, APIS MELLIFICA
}

\begin{abstract}
Afin d'avoir une idée du caractère cyclique du couvain plâtré dans les colonies d'abeilles, on a pulvérisé des suspensions d'Ascosphaera apis, préparées à partir de larves momifiées ayant sporulé, 3 fois par semaine sur les rayons de couvain et les abeilles présentes sur ces rayons, dans 12 colonies et ce durant 4 mois à partir d'août. Pendant 9 mois on a récolté les larves momifiées dans les trappes à abeilles mortes et sur le plancher des ruches et on les a comptées dans les cellules de couvain. Pendant 7 mois on a recherché chez les abeilles la présence d'A. apis par des tests microbiologiques sur plaques.

Deux périodes principales d'infection ont eu lieu : la première, une semaine après le début de l'inoculation par pulvérisation, la seconde en novembre. La seconde infection semble liée à une perturbation nutritionnelle. La sensibilité à la maladie des colonies contaminées par inoculation a varié de zéro à un degré élevé. Il a fallu 5 mois après la dernière pulvérisation pour que la plupart des éléments de la colonie soient indemnes d'A. apis, bien qu'une contamination faible ait persisté dans le pain d'abeilles, le miel et l'intérieur des larves des cellules operculées. Le pathogène peut survivre dans les colonies d'abeilles sans causer ouvertement de maladie.

Ces résultats soulignent la nécessité de développer des recherches pour définir les facteurs de stress qui favorisent le couvain plâtré dans diverses régions géographiques, pour déterminer pourquoi seules certaines colonies et certaines abeilles sont sensibles et pour éclaircir les mécanismes déclencheurs nécessaires à l'apparition de la maladie.
\end{abstract}




\section{ZUSAMMENFASSUNG \\ INFEKTIOSITÄT UND UBBERLEBEN DES KALKBRUTERREGERS, ASCOSPHAERA APIS, IN VÖLKERN DER HONIGBIENE, APIS MELLIFERA}

Um in das rezidivierende Auftreten der Kalkbrutkrankheit in Bienenvölkern Einblick zu gewinnen, wurden 4 Monate lang, beginnend im August, Suspensionen von Ascosphaera apis aus sporulierten Kalkbrutmumien hergestellt und dreimal wöchentlich auf die Brutwaben und die darauf sitzenden Bienen von 12 Völkern gesprüht. Neun Monate hindurch wurden Mumien aus Bienenfallen und vom Bodenbrett gesammelt sowie in Wabenzellen gezählt. Sieben Monate hindurch wurden Bienen, Brut und Bienenprodukte mikrobiologisch durch Ausstrichverfahren auf $\boldsymbol{A}$. apis getestet.

Es traten zwei Hauptinfektionsperioden auf, die erste eine Woche nach der Inokulation durch Besprühen und die zweite im November. Die zweite Infektion schien mit einem Ernährungsstreß in Zusammenhang zu stehen. Die Krankheitsanfälligkeit der inokulierten Völker schwankte zwischen Null und Hoch. Es dauerte 5 Monate, gerechnet von der letzen Sprühung, bis die meisten Substrate in den Völkern frei von $A$. apis waren; ein geringer Befall blieb jedoch in Bienenbrot, Honig und im Körper der Larven aus verdeckelten Zellen erhalten. Die Krankheitskeime können in Bienenvölkern überleben, ohne eine manifeste Krankheit zu verursachen.

Diese Ergebnisse unterstreichen die Notwendigkeit, weitere Forschungen durchzuführen um die Streßfaktoren zu bestimmen, die in verschiedenen geographischen Gebieten die Kalkbrutkrankheit fördern, herauszufinden, warum nur einige Bienenvölker und Larven anfällig sind, und um den auslösenden Mechanismus zu entdecken, der für die Entstehung der Krankheit erforderlich ist.

\section{LITERATURE}

BaILEY L., 1967. - The effect of temperature on the pathogenicity of the fungus, Ascosphaera apis, for larvae of the honeybee, Apis mellifera. In «Insect Pathology and Microbial Control», ed. P.A. van der LaAn, North Holland Publishing Co., Amsterdam, 162-167.

Christensen M., Gilliam M., 1983. - Notes on the Ascosphaera species inciting chalkbrood in honey bees. Apidologie, 14, 291-297.

Gilliam M., Taber S. III, Richardson G.V., 1983. - Hygienic behavior of honey bees in relation to chalkbrood disease. Apidologie, 14, 29-39.

Gochnauer T.A., Margetts V.J., 1980. - Decontaminating effect of ethylene oxide on honeybee larvae previously killed by chalkbrood disease. J. Apic. Res., 19, 261-264. 